\title{
Catalytic Performance of Cow-Dung Sludge in Water Treatment Mitigation and Conversion of Ammonia Nitrogen into Nitrate
}

\author{
Lokesh Kumar ${ }^{1, *(\mathbb{D})}$, Jaigopal Sharma ${ }^{2}$ and Raminder Kaur ${ }^{3, *(1)}$ \\ 1 Department of Applied Chemistry, Delhi Technological University, Delhi 110042, India \\ 2 Department of Biotechnology, Delhi Technological University, Delhi 110042, India; \\ sharmajaigopal@yahoo.com \\ 3 Department of Polymer Science and Chemical Technology, Delhi Technological University, Delhi 110042, India \\ * Correspondence: lokeshdjb@gmail.com (L.K.); raminderkaur@dce.ac.in (R.K.); Tel.: +91-9818863285 (L.K.); \\ +91-9717212152 (R.K.)
}

check for updates

Citation: Kumar, L.; Sharma, J.; Kaur,

R. Catalytic Performance of Cow-Dung Sludge in Water Treatment Mitigation and Conversion of Ammonia Nitrogen into Nitrate. Sustainability 2022, 14, 2183.

https://doi.org/10.3390/su14042183

Academic Editors: Sanjeev Kumar

Prajapati, Halis Simsek

and Silvia Fiore

Received: 31 December 2021

Accepted: 8 February 2022

Published: 14 February 2022

Publisher's Note: MDPI stays neutral with regard to jurisdictional claims in published maps and institutional affiliations.

Copyright: () 2022 by the authors Licensee MDPI, Basel, Switzerland. This article is an open access article distributed under the terms and conditions of the Creative Commons Attribution (CC BY) license (https:// creativecommons.org/licenses/by/ $4.0 /)$.

\begin{abstract}
The present research study was performed to find a solution for the mitigation of ammonia nitrogen in municipally treated sewage effluent (MTSE) using two natural bio-resources. One was composted cow-dung sludge that had catalytic enzymes and nitrifying bacterial mass, and the second was Yucca extract (a desert plant). MTSE samples put in one-liter beakers/jars having initial ammonia nitrogen content of $34.78 \mathrm{mg} / \mathrm{L}$, when treated with $0.0 \mathrm{~g} / \mathrm{L}$ (control Sample), $1 \mathrm{~g} / \mathrm{L}, 5 \mathrm{~g} / \mathrm{L}$ (cowdung) and $10 \mathrm{mg} / \mathrm{L}, 50 \mathrm{mg} / \mathrm{L}$ (Yucca extract), respectively, reported depletion of ammonia nitrogen to about $0.00 \mathrm{mg} / \mathrm{L}$ ammonia $\left(\mathrm{NH}_{3}\right)$ as $\mathrm{N}$. It $\left(\mathrm{NH}_{3}\right)$ transformed to $17.8,0.18,0.09,18.65$, and $18.85 \mathrm{mg} / \mathrm{L}$ nitrite asN. Ammonia converted to $21.8,110.1,133.5,20.5,20.8 \mathrm{mg} / \mathrm{L}$ nitrate asNO 3 , respectively. After eight days of treatment, the jar test apparatus reported the results at 35 rounds per minute (RPM) and a temperature of $32{ }^{\circ} \mathrm{C}$. It was found that digested cowdung acted catalytically in eliminating the ammonia nitrogen by converting it to nitrate in a short period of nearly eight days, leading to almost $100 \%$ ammonia conversion.
\end{abstract}

Keywords: municipal sewage; biological treatment; ammonia nitrogen; cow-dung sludge; yucca extract

\section{Introduction}

Today, globally, drinking water sources have either been polluted or are under continuous threat of contamination by wastewater intrusion. Ammonia pollution in water has become a significant concern for environmentalists, chemists, and biologists due to the health hazards. There is a necessity for an appropriate technology that can accelerate nitrification by which ammonia nitrogen can be converted to stable compounds such that its adverse effects could be neutralized. Mere aeration in wastewater for biological stabilization of biological oxygen demand (BOD) and nitrification takes an extended time [1,2]. The elevated nitrogen concentrations in the surface waters have primarily resulted from modern agricultural practices, mainly due to nitrogen fertilizers [3-5]. However, the nitrogen discharge from the point sources, such as sewage treatment plants and industries, also contributes significantly to riverine nitrogen loading. Ammonia exists in the water in both organic and inorganic nitrogen. Organic nitrogen $(\mathrm{ON})$ includes a wide variety of compounds derived from natural and anthropogenic sources. The natural sources are principally nitrogenous end products of biological metabolism. Agricultural fertilizers also aid in the anthropogenic cause of organic nitrogen. Many bacteria, such as species of Nitrosomonas, possess the enzymeurease, which catalyzes the conversion of urea to in organic nitrogen (IN) forms, like Ammonia $>\left(\mathrm{NH}_{3}\right)$ orammoniumion $\left(\mathrm{NH}_{4}{ }^{+}\right)$, that further oxidize to nitrite by the process of nitrification [6-8]. The wastewater rich in ammonia nitrogen harms the environment significantly as the ammonia nitrogen may inhibit natural nitrification, cause water hypoxia, result in fish poisoning, and decrease the water purifica- 
tion capacity $[4,5,8]$. Composted cowdung was studied to analyze its catalysis properties in accelerating nitrification.

\section{Ammonia Nitrogen in the Water and Discharge Limit}

Ammonia nitrogen exists in water in two forms, free or unionized ammonia $\left(\mathrm{NH}_{3}\right)$ and ionized ammonium $\left(\mathrm{NH}_{4}{ }^{+}\right)$[9], and both these forms are $\mathrm{pH}$ and temperature dependent [10]. In aqueous ammonia solutions, the un-ionized ammonia exists in equilibrium with the ammonium and hydroxide ions [10]. Central Pollution Control Board (CPCB), a statutory organization of the Indian Government, has amended its discharge standards for sewage under the Water (Prevention and Control of Pollution) Act, 1974, vide order No. A-10014/43/06-MON/709 dated 21 April 2015, and further proceedings of the 199th Board meeting held on the 8 September 2015. The new standard for ammonia nitrogen in the treated sewage has stipulated that it is not more than $5 \mathrm{mg} / \mathrm{L}$ and that total nitrogen is not more than $10 \mathrm{mg} / \mathrm{L}$. Previously the standard values for ammonia nitrogen were limited to the extent of $50 \mathrm{mg} / \mathrm{L}$ and that of total nitrogen or total Kjeldahl nitrogen $100 \mathrm{mg} / \mathrm{L}$ [11].

\section{Available Techniques and Demerits on Mass-Scale Treatment}

There are many techniques for removing ammonia nitrogen from waste water, such as nitrification-denitrification, ammonia stripping, ion exchange, zeolite process, breakpoint chlorination, and algae ponds. Still, none are free from the operational complications [1,12-16]. Moreover, the available techniques are not feasible for large water masses, as are required by municipal sewage disposal works in large cities [17-21]. Secondary treated sewage effluents require treatment so that the ammonia nitrogen can be converted into nitrate without any limitations/demerits of the process. In some cases, the growth of algae is also a problem. The ammonia nitrogen contributes to the development of the algal bloom in the presence of bluish-white light, as it accumulates in the algae's moiety. The algal growth increases the $\mathrm{pH}$ of the water. It produces cyanotoxins [22]. When disinfected with chlorine, it creates a problem of filter bed choking in the water treatment utilities and hinders the water treatment process by making coagulants ineffective at water treatment plants. Higher $\mathrm{pH}$ of water (>8.2), as sometimes faced at municipal waterworks of Delhi (India), creates hindrance in the conventional water treatment processes, as it makes the chlorine ineffective. Furthermore, the coagulant poly aluminum chloride is inefficient at higher $\mathrm{pH}[23]$.

\section{Focus on New Research: Catalytic Effect of Cow-Dung Sludge}

The present studies have been conducted to combat the ammonia nitrogen in the secondary treated municipal sewage water by using a desert plant extract, Yucca schidigera, and cowdung. However, Yucca extract has been reported in some previous studies for its capability of removing ammonia nitrogen from the water [24-27]. The experimental studies conducted using the cowdung on treated sewage yielded better results for combating the ammonia nitrogen and have shown its potential to be applied in real life for large masses of wastewater. In addition to cowdung, Blue-buck dung and Buffalo dung, both fresh and digested, were also employed for the studies on removing ammonia nitrogen, but the digested cowdung was found to be effective.

\section{CowDung as a Bioresource of Catalytic Enzymes and Nitrifying Bacterial Mass}

The cowdung has been used successfully in previous studies for industrial wastewater treatment for combating heavy metals, pharmaceuticals, pesticides, and petrochemicals [28-32]. cowdung harbors a rich microbial diversity, containing different bacteria, protozoa, and yeast. Godambe and Fulekar [32] separated the species of bacteria: Enterobacter cloacae, Pseudomonas pseudoalcaligenes, Archromobacter sp., Aeromonashydrophila, Bacillus pumilis belonging to the genus of Pseudomonas sp., Escherichia sp., Staphylococcus sp., Aeromonas sp., Bacillus sp., Enterobacter sp. and yeast Rhizopus sp. In addition toprotozoa and yeasts (Saccharomyces and 
Candida), a beneficial bacterial mass of Citrobacterkoseri, Enterobacteraerogenes, Escherichia coli, Klebsiella oxytoca, Klebsiella pneumonia, Kluyvera spp., Morgarellamorganii, Pasteurella spp., Providenciaalcaligenes, Providenciastuartii, and Bacillus spp., Corynebacterium spp., and Lactobacillus spp. are present in cowdung [31,33]. Randhawa and Kullar (2011) found that the indigenous Indian cowdung contains more calcium, phosphorus, zinc, and copper than the cross-breed cowdung. Teo and Teoh (2011) studied five different isolates from the cowdung. They found that all isolates were positive for the presence of esterase and esterase lipase. All strains were able to produce protease, esterase, and esterase lipase. The protease is an enzyme that catalyzes proteolysis, which breaks down the proteins to their respective amino acids. Furthermore, they have a variety of applications, mainly in the detergent and food industries. Esterase and esterase lipase belonging to the hydrolase enzymes split esters into acids and alcohols, as was observed in a chemical reaction of the hydrolysis process involving the addition of water molecules [34]. Cowdung, containing a diverse group of microorganisms such as Acinetobacter, Bacillus, Pseudomonas, Serratia, and Alcaligenes spp., makes them suitable for microbial degradation of the pollutants $[29,35,36]$. The cowdung slurry maintained in the ratio of 1:10 or 1:25 can degrade the rural, urban, and hospital wastes, including oil spillage, to five essential elements [31].

Quaraishi et al. (2018) evaluated the performance of the cowdung as microbial inoculums in industrial wastewater treatment and found a significant reduction in chemical oxygen demand (COD). They observed a 45.7, 62.3 and $84.04 \%$ reduction on the 5 th, 10 th, and 15th day of treatment. The bacterial mass found in the cowdung offers practical bioremediation for treating hydrocarbon-benzene. In a study, benzene was degraded entirely from 50 and $100 \mathrm{mg} / \mathrm{L}$ concentration after 96 and $144 \mathrm{~h}$, respectively, whereas for $200 \mathrm{mg} / \mathrm{L}$, about 99 percent degradation was observed after 240 and for $400 \mathrm{mg} / \mathrm{L}$ up to $69.2 \%$ degradation observed. As per the study of Godambe and Fulekar, cowdung possesses a huge microbial load, Table 1 [32].

Table 1. Characteristics of Cow Dung.

\begin{tabular}{cc}
\hline \multicolumn{1}{c}{ Microbial Enumeration of the cow dung Sample } \\
\hline Parameters & Results \\
Total viable count & $2.29 \times 10^{8} \mathrm{cell} / \mathrm{ml}$ \\
Total Fungal count & $1.16 \times 10^{7} \mathrm{cell} / \mathrm{ml}$ \\
Yeast count & $7.5 \times 10^{6} \mathrm{cfu} / \mathrm{ml}$ \\
Physico-Chemical Characterization of a Cow Dung Sample \\
pH & 7.3 \\
Dissolved Oxygen & $6.4 \mathrm{mg} / \mathrm{L}$ \\
Temperature & $25.9{ }^{\circ} \mathrm{C}$ \\
\% Organic Carbon & $0.67 \%$ \\
Biological Oxygen Demand & $19.83 \mathrm{mg} / \mathrm{L}$ \\
Chemical Oxygen Demand & $195.2 \mathrm{mg} / \mathrm{L}$ \\
Phosphorous & $0.23 \mathrm{mg} / \mathrm{L}$ \\
Sulphate & $38.5 \mathrm{mg} / \mathrm{L}$ \\
\hline The bold from the title it's important because it distinguishes between microbial and physico-chemical properties.
\end{tabular}

The cow dung consortium (bacteria, fungi, and actinomycetes) has also helped degrade phenol ranging from 100 to $1000 \mathrm{mg} / \mathrm{L}$ Table 2. The phenolic toxicant is converted to nutrients, biomass, and $\mathrm{CO}_{2}$ via biodegradation through their intermediates. Thus, cow dungcan potentially beused in the petrochemical and chemical industries, generating waste-containing phenol compounds [31,37].

However, there are no reports of cow dung being used in wastewater treatment specifically to combat ammonia nitrogen. India'sgovernment provides enormous funds on Scientific Validation and Research on Panchgavya (a concoction of cowdung, cow urine, milk, curd, and ghee). The present research presents a comparative study of Yucca extract and cow dung use for ammonia combat in wastewater. 
Table 2. Degradation of phenol with cow-dung slurry.

\begin{tabular}{ccc}
\hline Concentration of Phenol & Degradation $\%$ & Time Duration \\
\hline $100 \mathrm{mg} / \mathrm{L}$ & 98.59 & $24 \mathrm{~h}$ \\
$250 \mathrm{mg} / \mathrm{L}$ & 99.4 & $72 \mathrm{~h}$ \\
$500 \mathrm{mg} / \mathrm{L}$ & 99.6 & $96 \mathrm{~h}$ \\
$1000 \mathrm{mg} / \mathrm{L}$ & Not degraded & up-to $168 \mathrm{~h}$ \\
\hline
\end{tabular}

However, there are no reports of cow dung being used in wastewater treatment specifically to combat ammonia nitrogen. India'sgovernment provides enormous funds on Scientific Validation and Research on Panchgavya (a concoction of cowdung, cow urine, milk, curd, and ghee). The present research presents a comparative study of Yucca extract and cow dung use for ammonia combat in wastewater.

\section{Materials and Methods}

\subsection{Collection of Samples and Testing}

The $25 \mathrm{~L}$, secondary treated sewage effluent samples were collected from Sewage Disposal Works (SDW), Delhi, India. This SDW treats about 40 MGD municipal sewage using the activated sludge method. The collected sample was immediately tested for the initial parametric values of ammonia nitrogen, nitrite, nitrate, $\mathrm{pH}$ value, total dissolved solids, electrical conductivity, temperature, etc. The ammonia nitrogen, nitrite, and nitrate tests were performed on Eppendorf Bio Spectrometer model 2019 (Eppendorf AG, Hamburg, Germany). The ammonia nitrogen was tested as per the Nesslerization method, 4500- $\mathrm{NH}_{3} \mathrm{C}$, Nitrite by $4500-\mathrm{NO}_{2}{ }^{-} \mathrm{B}$, and Nitrate by $4500-\mathrm{NO}_{3}{ }^{-} \mathrm{B}$, prescribed in the standard methods for the examination of water and waste water [38]. The $\mathrm{pH}$ values, total dissolved solids, and electrical conductivity were measured by a Hach HQ $440 \mathrm{~d}$ Multi Ion Analyser, Loveland. Colorado, United State The authors prepared standard solutions for ammonia nitrogen, nitrite, and nitrate tests designed from analytical-grade reagents for calibration purposes.

\subsection{Preparation of Yucca Extract}

Yucca schidigera, a desert plant, was collected from the Forest Research Institute, Dehradun, Uttrakhand State, India. The Yucca plant's stem (about $250 \mathrm{~g}$ ) was cut and chopped with a knife into small pieces. Then, the chopped pieces were ground in a grinder mixture, dried in the open sun for three days, and again dropped to make a fine powder. This Yucca powder was sieved through a 150-mesh sieve and stored in an airtight container. In the present study, the Yucca extract was used in the form of a solution. Yucca solution was prepared by mixing and dissolving $50 \mathrm{~g}$ of Yucca powder in $700 \mathrm{~mL}$ distilled water in a $1 \mathrm{~L}$ beaker, stirred on jar test apparatus for seven days (about $250 \mathrm{~mL}$ water wasevaporated in the air) so that its contents could dissolve well, filtered through ordinary filter paper and made up to $500 \mathrm{~mL}$ with distilled water in a measuring flask. Thus, $1 \mathrm{~mL}$ of Yucca extract produces $100 \mathrm{mg}$ solution.

\subsection{Preparation of Indian Cow Dung}

The cow dung was collected locally from a heap dumped by a farmer in a village of Delhi. The age of the cow-dung pile was about one year old. The digested wet darkbrown colored cow dung, about $500 \mathrm{~g}$, was taken from a depth of 6 inches inside the heap in a clean glass bottle. Collected cow dung was ready to be used. A total of $1 \mathrm{~g}$ of cow dung was weighed in an electronic balance three times and poured into three different beakers containing $1 \mathrm{~L}$ of municipally treated sewage effluent (MTSE) in each. The experiments were performed in triplicate, and the average of all was taken for calculation purposes. Similarly, other operations were performed with a higher amount of cow-dung sludge $(2-5 \mathrm{~g})$. 


\subsection{Experimental Setup and Oxidation of Ammonia Nitrogen}

The jar test apparatus (Figure 1) was used to observe the biomass's effectiveness (Yucca extract and cow dung) with a stirring speed of 35 RPM. The experiments were carried out in triplicate for more precise results. Because of the jar test apparatus's limitations, the triplicate samples were treated separately because it had only a six-beaker arrangement. The reported results are the final valid values extracted after several experiments under varying experimental conditions. The collected MTSE were taken into the six one-liter beakers.

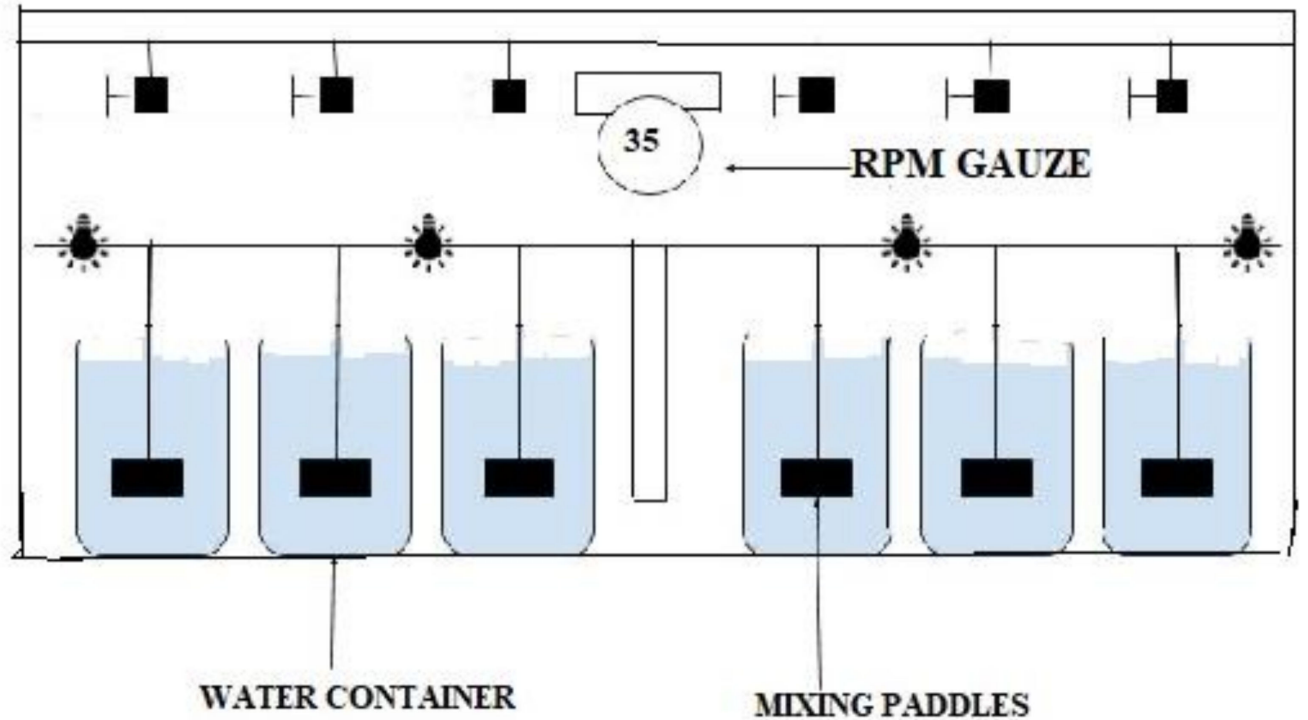

Figure 1. Experimental Setup-Jar Test Apparatus.

Parameters for ammonia nitrogen, nitrite, nitrate, $\mathrm{pH}$, electrical conductivity, total dissolved solids, color, odor, and temperature were tested immediately in the laboratory after sample collection. We kept beakers 1 and 2 for reference. Beaker 1 served as a control to measure the amount of water evaporated during the experiment. Beaker 2 served as a control to measure the change in parameters naturally. We added 1and $5 \mathrm{~g}$ of cow dung into the beakers 3 and 4 while 0.1 and $0.5 \mathrm{~mL}$ of Yucca extract was added to beakers 5 and 6, respectively. Four 15-watt tungsten bulbs were hung over the jar test apparatus to illuminate the system round the clock. The stirrers of the equipment are set at 35 RPM. Every $48 \mathrm{~h}$, a $100 \mathrm{~mL}$ sample was taken from the jars numbered from 2 to 6 and tested for changes in parameters. We used the content of beaker 1 for measuring the quantity of water evaporated during the processing period of 48 (2 days), 96 (4 days), 144 (6 days), and 192 (8 days) h, respectively.

\section{Results and Discussions}

Initially, Yucca schidigera extract was used with varying concentrations in the presence and absence of lights. We measured initial levels ofammonia nitrogen and other parameters of MTSE, and the experiments were performed at room temperature with pristine samples. It was observed that, even with multiple experimental studies using the different dosages of Yucca extract, there was no significant difference in the concentration of ammonia nitrogen, nitrite, and nitrate with the control sample. Instead, the ammonia nitrogen found increased in the Yucca extract dosed samples after the 8th day. An increase in ammonia content indicated that the Yucca extract started fermenting after the 6th day. The Yucca extract did not help combat ammonia nitrogen in municipal sewage water. After this, the experiments were conducted using the excreta of the bovine animals such asBlue-buck, Buffalo, and Cow, as a potential bioresource to combat the ammonia nitrogen from wastewater. Among all these, the cow dung was found most effective against removing ammonia nitrogen. As per the previously reported studies, the cow dung was very effective against reducing the 
effluent's chemical oxygen demand (COD) [30]. COD is the amount of oxygen required to stabilize organic and inorganic (ammonia and nitrite) pollutants in water under heat and acidic conditions, using a highly oxidizing agent, potassium dichromate, corrected for the influence of chloride. The cow dung, in this case, acted as a bio-catalyst.

\subsection{Biological Oxidation of Ammonia Nitrogen}

We experimented with digested cow dung, and it was found that catalytical enzymes and nitrifying bacteria present in cow dung reduced ammonia significantly. The results of the present study aredepicted in Figure 1, wherein an initial amount of $34.780 \mathrm{mg} / \mathrm{L}$ ammonia nitrogen (as $\mathrm{NH}_{3}$ ) in municipally treated sewage effluent (MTSE)was reduced to 23.210 (in control sample), 22.590 (with $1 \mathrm{~g} / \mathrm{L}$ cow dung), $18.390 \mathrm{mg} / \mathrm{L}$ (with five $\mathrm{g} / \mathrm{L}$ cow dung), $23.580 \mathrm{mg} / \mathrm{L}$ (with $10 \mathrm{mg} / \mathrm{L} Y u c c a$ extract) and $24.705 \mathrm{mg} / \mathrm{L}$ (with $50 \mathrm{mg} / \mathrm{L}$ Yucca extract) in $48 \mathrm{~h}$ or the 2 nd day of the process at $32^{\circ} \mathrm{C}$ temperature and $35 \mathrm{RPM}$. In $96 \mathrm{~h}$, or the 4 th day of the experimental set-up, ammonia nitrogen was reduced to $2.040,0.960,1.390,2.735$ and $7.135 \mathrm{mg} / \mathrm{L}$, respectively. In $144 \mathrm{~h}$, or the 6 th day, ammonia nitrogen was reduced to $0.032,0.00,0.00,0.036$ and $0.154 \mathrm{mg} / \mathrm{L}$. In $192 \mathrm{~h}$, or the 8th day, ammonia nitrogen had been reduced to $0.00,0.00,0.00,0.00$ and $0.88 \mathrm{mg} / \mathrm{L}$, respectively (Figure 2).

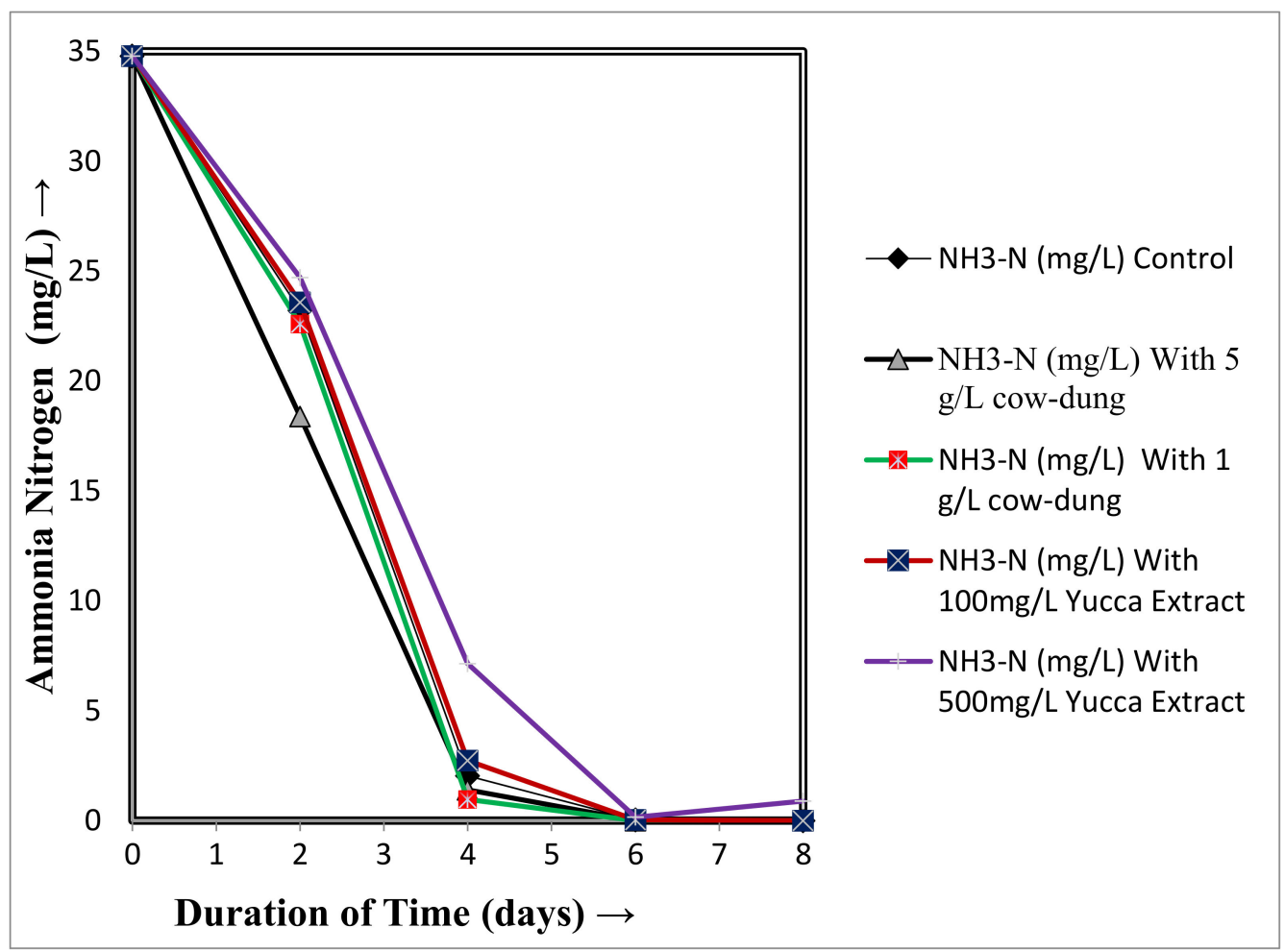

Figure 2. Biological Oxidation of Ammonia Nitrogen. (In Control, with Cow Dung and Yucca extract).

\subsection{Biological Oxidation of Nitrite to Nitrate}

Figure 2 shows the oxidation of nitrite $\left(\mathrm{NO}_{2}\right)$ into nitrate $\left(\mathrm{NO}_{3}\right)$. The initial content of ammonia nitrogen in municipally treated sewage effluent (MTSE) is converted to nitrite and nitrate simultaneously. The conversion of ammonia into nitrite and nitrate in biological oxidation is a continuous process. Experimental study explored that the effluent with aninitial amount of $34.789 \mathrm{mg} / \mathrm{L}$ ammonia nitrogen and $0.150 \mathrm{mg} / \mathrm{L}$ nitrite nitrogen has converted or oxidized to $0.210 \mathrm{mg} / \mathrm{L}$ (in blank), $2.880 \mathrm{mg} / \mathrm{L}$ (with $1 \mathrm{~g} / \mathrm{L}$ cow dung), $3.265 \mathrm{mg} / \mathrm{L}$ (with $5 \mathrm{~g} / \mathrm{L}$ cow dung), $0.545 \mathrm{mg} / \mathrm{L}$ (with $10 \mathrm{mg} / \mathrm{L} \mathrm{Yucca} \mathrm{extract)} \mathrm{and} 0.575 \mathrm{mg} / \mathrm{L}$ (with $50 \mathrm{mg} / \mathrm{L}$ Yucca extract) into nitrite $\left(\mathrm{NO}_{2}\right)$ in $48 \mathrm{~h}$, or the 2 nd day of the process, at $32{ }^{\circ} \mathrm{C}$ temperature and 35 RPM. In $96 \mathrm{~h}$, or the 4 th day of the experimental set-up, ammonia nitrogen oxidized 
to $11.70,16.15,11.45,13.525$ and $9.60 \mathrm{mg} / \mathrm{L}$ nitrite $\left(\mathrm{NO}_{2}\right)$, respectively. In $144 \mathrm{~h}$, or the 6th day, ammonia nitrogen was converted to nitrite (which further kept oxidizing to nitrate) as $14.70,8.80,0.30,15.525$ and $14.375 \mathrm{mg} / \mathrm{L}$. In $192 \mathrm{~h}$, or the 8th day, ammonia nitrogen oxidized to $17.80,0.18,0.09,18.65$ and $18.85 \mathrm{mg} / \mathrm{L}$ nitrite $\left(\mathrm{NO}_{2}\right)$, respectively (Figure 3).

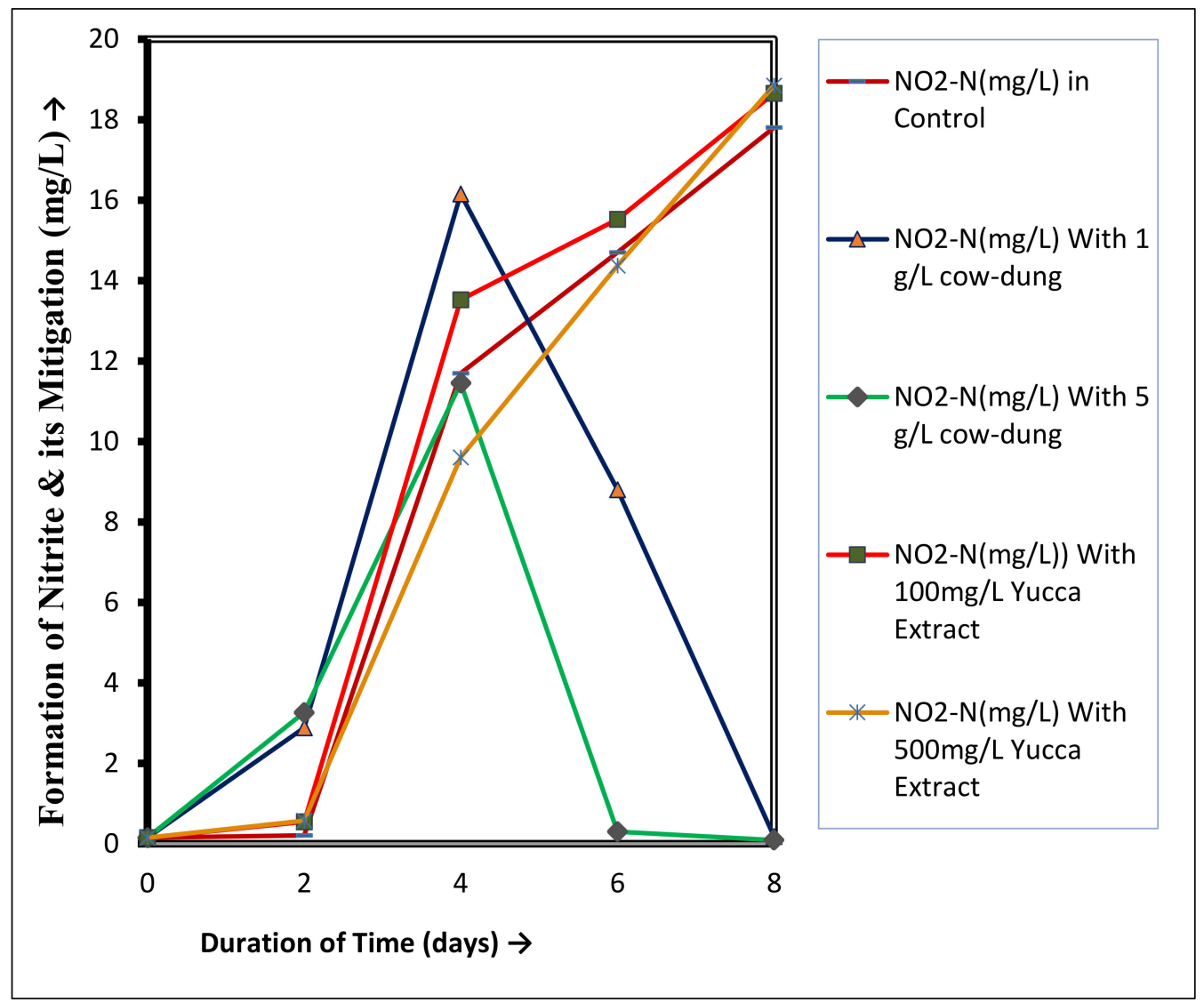

Figure 3. Formation of nitrite nitrogen during oxidation of ammonia nitrogen (in control, with cow dung and Yucca extract).

\subsection{Oxidation of Nitrite $\left(\mathrm{NO}_{2}\right)$ into Nitrate $\left(\mathrm{NO}_{3}\right)$}

Ammonia nitrogen is readily converted to nitrite biologically, but its further oxidation to nitrate (a stable form) is typical. It has been observed that the oxidation of nitrite into nitrate is recalcitrant. Cow dung accelerated the process of nitrification. Figure 4 shows that theinitial amount of $34.789 \mathrm{mg} / \mathrm{L}$ ammonia nitrogen and $0.45 \mathrm{mg} / \mathrm{L}$ nitrate as $\mathrm{NO}_{3}$ converted or oxidized to $2.25 \mathrm{mg} / \mathrm{L}$ (In blank), $3.80 \mathrm{mg} / \mathrm{L}$ (with $1 \mathrm{~g} / \mathrm{L}$ cow dung), $11.70 \mathrm{mg} / \mathrm{L}$ (with $5 \mathrm{~g} / \mathrm{L}$ cow dung), $1.60 \mathrm{mg} / \mathrm{L}$ (with $10 \mathrm{mg} / \mathrm{L} Y u c c a$ extract) and $2.35 \mathrm{mg} / \mathrm{L}$ (with $50 \mathrm{mg} / \mathrm{L}$ Yucca extract) into nitrate $\left(\mathrm{NO}_{3}\right)$ in $48 \mathrm{~h}$, or the 2 nd day of the process, at $32{ }^{\circ} \mathrm{C}$ temperature and $35 \mathrm{RPM}$. In $96 \mathrm{~h}$, or the 4 th day of the experimental set-up, ammonia nitrogen oxidized to $12.90,22.25,59.30,11.75$ and $8.05 \mathrm{mg} / \mathrm{L}$ nitrate $\left(\mathrm{NO}_{3}\right)$, respectively. In $144 \mathrm{~h}$, or the 6th day, ammonia nitrogen was converted to nitrate as $16.60,67.30,109.0$, 17.80 and $17.0 \mathrm{mg} / \mathrm{L}$. In $192 \mathrm{~h}$, or the 8th day, ammonia nitrogen oxidized to 21.80, 110.10, 133.5, 20.50 and $20.80 \mathrm{mg} / \mathrm{L}$ nitrate $\left(\mathrm{NO}_{3}\right)$, respectively (Figure 4).

The ammonia nitrogen is completely converted to its final and stable product nitrate in 6 to 8 days, depending on the amount of cow dungused. However, the samples' total dissolved solids have been found to increase due to water evaporation during ammonia nitrogen oxidation. Because of evaporation, there was 5.7, 10.2, 15.7 and $21.9 \%$ water loss on the $2 \mathrm{nd}, 4 \mathrm{th}, 6 \mathrm{th}$, and 8 th day of the experimental process.

We also determined the effect of the cow dung and Yucca extract dosing on different parameters such as ammonia, nitrite, nitrate, $\mathrm{pH}$, electrical conductivity, and Total Dissolved 
Solids (TDS). We found both light and temperature to affect ammonia removal significantly. During the initial experimental studies, it has been seen that, in the absence of light and at a low temperature (below $30^{\circ} \mathrm{C}$ ), the nitrite (intermediate product) could not be converted to nitrate substantially. In some cases, intense white light illuminated by LED bulbs resulted in algal growth. The development of algae in the samples hindered the conversion of nitrite into nitrate, increased high $\mathrm{pH}$ to about ten, and algae grew out into large masses. However, the total dissolved solids decreased substantially. The tungsten bulbs were found fit for illuminations, as they did not support the algal formation in the samples.

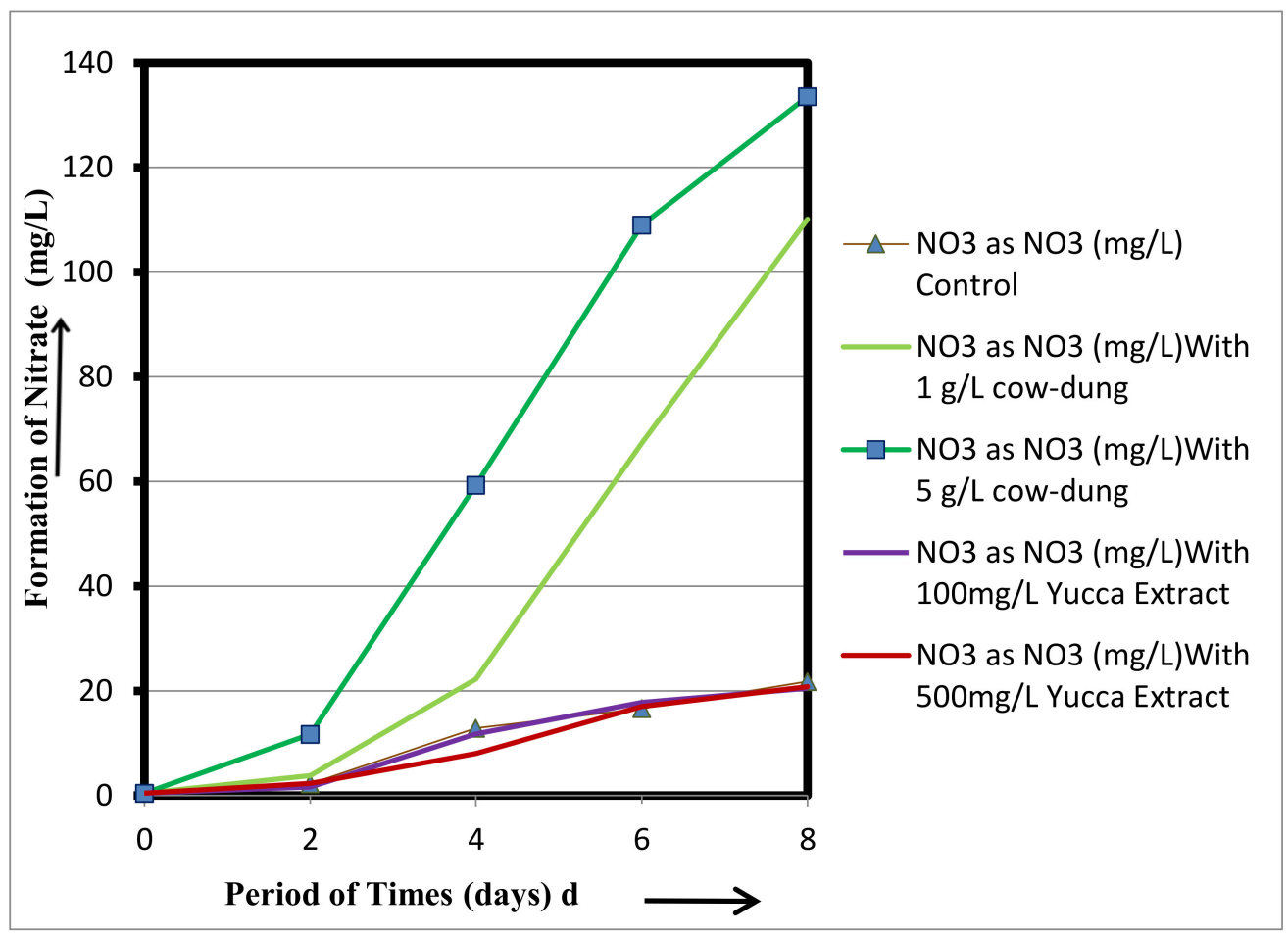

Figure 4. Conversion of ammonia nitrogen into nitrate (in control, with cow dung and Yucca extract).

The conversion of ammonia nitrogen into the stable nitrate form is a very typical mechanism. In general practice, the treated effluent's mechanical stirring oxidizes the ammonia nitrogen to nitrite in the presence of nitrifying bacteria and natural oxidation. However, nitrite is also as harmful as ammonia regarding the production of disinfection by-products. In the present experimental study, the conversion of ammonia nitrogen into nitrite and nitrite into nitrate is simultaneous. However, the cow dung (digested) contributes to adding an insignificantly small amount of ammonia nitrogen to the samples. This negligible amount has not been counted for the sake of convenience. The authors analyzed the exact maximum amount of nitrite and nitrate formation.

Based on the current experimental studies, the addition of the cow dung and a few additional modifications in the existing conventional sewage treatment plants' existing infrastructure can give better final effluent quality, free from ammonia nitrogen and nitrite pollution. The proposed design of a modified sewage treatment plant working on the activated sludge process has been suggested in Figure 5, including tertiary treatment units. Here, Hydraulic Retention Time (HRT) in the Flocculator chamber with RPM 35 is eight days for the biological oxidation of ammonia nitrogen $\left(\mathrm{NH}_{3}-\mathrm{N}\right.$ into nitrate $\left.\left(\mathrm{NO}_{3}\right)\right)$.

Cow dung is abundantly available in India. Using cow dung as a bio-resource in wastewater treatment plants is safe and environmentally friendly because cow dung and cow urine are used to treat several human diseases in Indian herbal and natural treatment systems [39-41]. Activated sludge from the final settling tank has to take to feed the aeration 
tank. It would be required to maintain a temperature of 32 to $38^{\circ} \mathrm{C}$ of the mesophilic temperature range as microbiological activities are more prominent at higher temperatures.

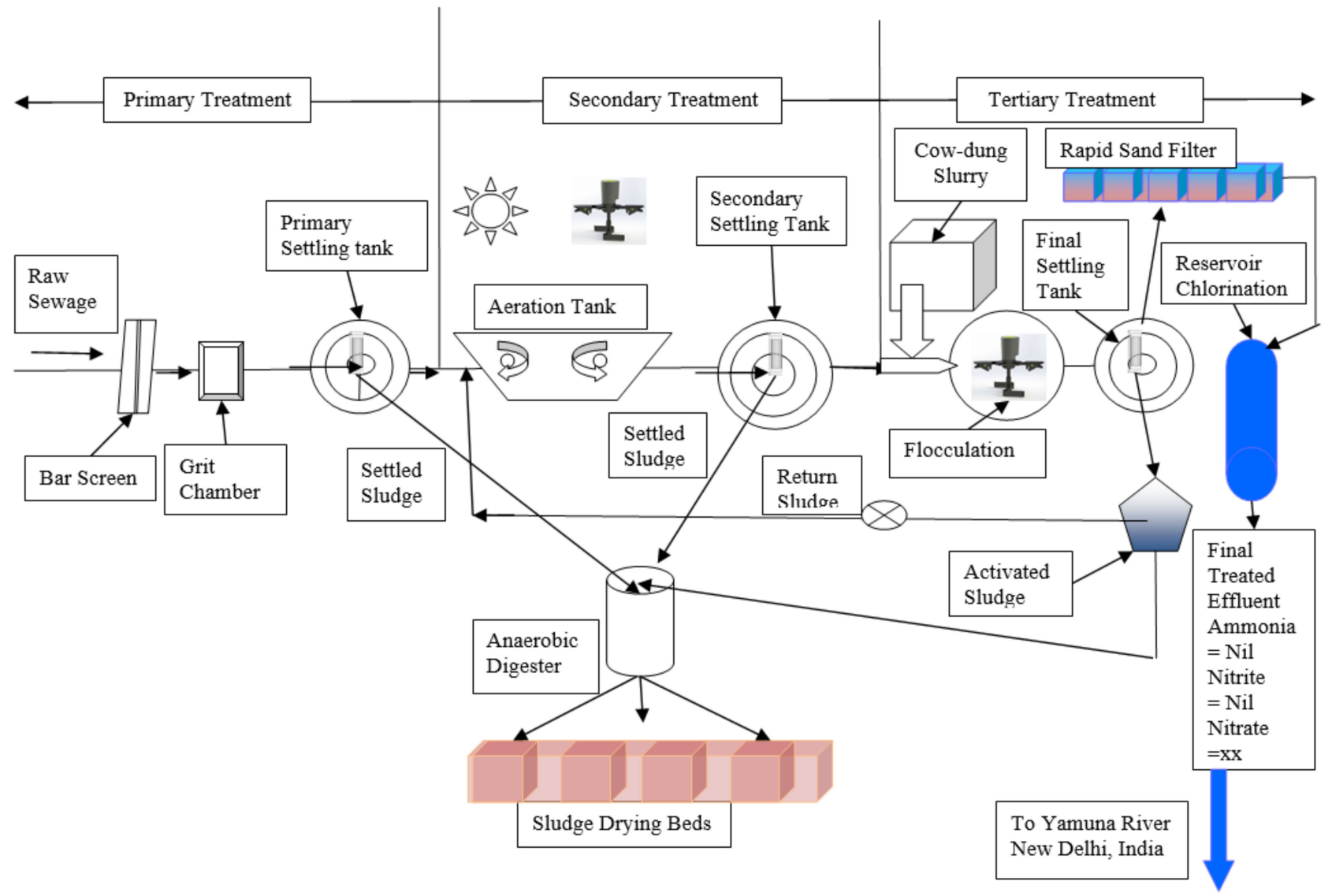

Figure 5. Proposed Sewage Treatment Plant with Biological Tertiary Treatment Units.

Cow dung has successfully proved to play an important role in wastewater treatment. Even cow dung ash has been found active in water disinfection [42]. The dried powder form of cow dung is also helpful as a green adsorbent material to remove carcinogenic and heavy metal water pollutants [28,43]. FAO, 1998 mentioned that cow dung and cow urine possess complex degrading substances [44].

\section{Conclusions}

The digested cow dung is an excellent biological remedy for the complete treatment of wastewater for combating ammonia nitrogen. The worldwide water scarcity can be mitigated by reusing properly treated municipal sewage and industrial effluents to augment water resources and a circular economy. In the current study, 1gcow dung has transformed $34.78 \mathrm{mg} / \mathrm{L}$ ammonia nitrogen in a municipally treated sewage effluent to $110.1 \mathrm{mg} / \mathrm{L}$ nitrate on the 8th day under aerobic conditions and a temperature of $32{ }^{\circ} \mathrm{C}$ performed with jar test apparatus at $35 \mathrm{RPM}$. At the same experimental conditions, the higher amount of cow dung of $5 \mathrm{mg} / \mathrm{L}$ mitigated ammonia nitrogen rapidly and yielded $133.5 \mathrm{mg} / \mathrm{L}$ nitrates. Most importantly, cow dung proved to be capable of transforming to the extent of $99.4 \%$ an intermediate product nitrite, as hazardous as ammonia. The presence of numerous microbiological organisms and biocatalysts in cow dung makes it a faster and more efficient way to treat ammonia nitrogen-contaminated wastewater. Secondly, cow dung may be rich in Nitrosospira, Nitrosomonas, Nitrospira, and Nitrobacter, which may assist in converting ammonia nitrogen to nitrite and nitrate. Cow dung can also be an excellent bio-resource for the biological treatment of sewage effluent, municipal, hospital, pharmaceutical, and industrial solid/ liquid wastes. For further research, a case study is recommended in the 
existing activated sludge plant (SDW) using digested cow-dung slurry to study ammonia nitrogen conversion at the aeration chamber so that the present research can be utilized in real-life projects.

Author Contributions: Execution of experimental work and preparation of standard solutions and reagents, L.K.; Conceptualization, R.K.; Formal analysis, R.K.; Writing manuscript, R.K.; Corresponding R.K. and J.S.; Supervision, R.K.; Writing-review and editing, L.K.; Proposing experimental setup, J.S.; Interpreting results, J.S.; Supervising analytical work, J.S.; Providing instruments, J.S. All authors have read and agreed to the published version of the manuscript.

Funding: No Funding was provided for this research work.

Informed Consent Statement: Not Applicable.

Data Availability Statement: The datasets generated during and analyzed during the current study are available from the corresponding author on reasonable request.

Acknowledgments: We are thankful to Delhi Technological University for providing us with the necessary facilities to conduct these studies.

Conflicts of Interest: The authors declare that they have no known competing financial interests or personal relationships that could have influenced the work reported in this paper. There are no conflict of interest.

\section{References}

1. Lawson, C.E.; Lücker, S. Complete ammonia oxidation: An important control on nitrification in engineered ecosystems? Curr. Opin. Biotechnol. 2018, 50, 158-165. [CrossRef] [PubMed]

2. Kumar, L.; Kaur, R.; Sharma, J. The efficiency of zeolites in water treatment for combating ammonia - An experimental study on Yamuna River water \& treated sewage effluents. Inorg. Chem. Commun. 2021, 134, 108978.

3. Grady, C.P.L.; Daigger, G.T.; Love, N.G.; Filipe, C.D.M. Biological Wastewater Treatment, 3rd ed.; CRC Press: Boca Raton, FL, USA, 2011; ISBN 9781420009637.

4. Spellman, F.R. Handbook of Water and Wastewater Treatment Plant Operations; CRC Press: Boca Raton, FL, USA, 2003; ISBN 0471084980.

5. Gray, N.F. Biology of Wastewater Treatment, 2nd ed.; Imperial College Press: London, UK; University of Dublin: Dublin, Ireland, 2004; ISBN 1-86094-328-4/1-86094-332-2.

6. Chen, G.H.; van Loosdrecht, M.C.; Ekama, G.A.; Brdjanovic, D. (Eds.) Biological Wastewater Treatment Principles, Modelling and Design; IWA Publishing: London, UK, 2008; ISBN 9781843391883.

7. Spellman, F.R. Mathematics Manual for Water and Wastewater Treatment Plant Operators; American Water Works Association: Denver, CO, USA, 2004; ISBN 1566706750.

8. Gerardi, M.H. Wastewater Microbiology: Nitrification and Denitrification in the Activated Sludge Process; John Wiley \& Sons: New York, NY, USA, 2002; ISBN 9780471065081.

9. EPA. Ambient Water Quality Criteria for Endosulfan; EPA: Washington, DC, USA, 1980.

10. Emerson, K.; Russo, R.C.; Lund, R.E.; Thurston, R.V. Aqueous Ammonia Equilibrium Calculations: Effect of pH and Temperature. J. Fish. Res. Board Can. 1975, 32, 2379-2383. [CrossRef]

11. The Environment (Protection) Rules. General standards for discharge of environment pollutants: Effluent. Gaz. Notif. MoEF 1986, 2, 545-560.

12. EPA. Wastewater Technology Fact Sheet-Ammonia Stripping (EPA 832-F-00-019); EPA: Washington, DC, USA, 2000; pp. 1-7.

13. De la Noue, J.; de Pauw, N. The potential of microalgal biotechnology: A review of production and uses of microalgae. Biotechnol. Adv. 1988, 6, 725-770. [CrossRef]

14. Prajapati, J.C.; Syed, H.S.; Chauhan, J. Removal of ammonia from wastewater by ion exchange technology. Int. J. Innov. Res. Technol. 2014, 1, 6-11.

15. Margeta, K.; Zabukovec, N.; Siljeg, M.; Farkas, A. Natural Zeolites in Water Treatment-How Effective is Their Use. Water Treat. 2013, 5, 81-112.

16. Mitch, W.A.; Sedlak, D.L. Formation of N-nitrosodimethylamine (NDMA) from dimethylamine during chlorination. Environ. Sci. Technol. 2002, 36, 588-595. [CrossRef]

17. Siciliano, A.; Curcio, G.M.; Limonti, C. Experimental analysis and modeling of nitrate removal through zero-valent magnesium particles. Water 2019, 11, 1276. [CrossRef]

18. Keerio, H.A.; Bae, W.; Park, J.; Kim, M. Substrate uptake, loss, and reserve in ammonia-oxidizing bacteria (AOB) under different substrate availabilities. Process Biochem. 2020, 91, 303-310. [CrossRef]

19. Keerio, H.A.; Bae, W. Experimental investigation of substrate shock and environmental ammonium concentration on the stability of ammonia-oxidizing bacteria (AOB). Water 2020, 12, 223. [CrossRef] 
20. Ramavandi, B.; Mortazavi, S.B.; Moussavi, G.; Khoshgard, A.; Jahangiri, M. Experimental investigation of the chemical reduction of nitrate ion in aqueous solution by $\mathrm{Mg} / \mathrm{Cu}$ bimetallic particles. React. Kinet. Mech. Catal. 2011, 102, 313-329. [CrossRef]

21. Ahmadi, M.; Rahmani, H.; Ramavandi, B.; Kakavandi, B. Removal of nitrate from aqueous solution using activated carbon modified with Fenton reagents. Desalination Water Treat. 2017, 76, 265-275. [CrossRef]

22. Kumar, L. Study of double breakpoints during chlorination of river Yamuna water, Delhi, India. Int. J. Water Resour. Environ. Eng. 2013, 5, 370-379. [CrossRef]

23. Environmental Protection Agency. Water Treatment Manuals: Coagulation, Flocculation E Clarification; EPA: Washington, DC, USA, 2002; ISBN 1840950900.

24. Cheeke, P.R.; Piacente, S.; Oleszek, W. Anti-inflammatory and anti-arthritic effects of yucca schidigera: A review. J. Inflamm. 2006, 3, 2-8. [CrossRef]

25. Santacruz-Reyes, R.A.; Chien, Y.H. Efficacy of Yucca schidigera extract for ammonia reduction in freshwater: Effectiveness analysis and empirical modeling approach. Aquaculture 2009, 297, 106-111. [CrossRef]

26. Yu, X.; Dimitriou, E.; Konstantinos, S.; Markogianni, V.; Politi, D. EFFECTS of yucca shidigera extract on the reduction of ammonia concentration in lake Koumoundourou. J. Ecol. Eng. 2015, 16, 1-7. [CrossRef]

27. Santacruz-Reyes, R.A.; Chien, Y.H. Yucca schidigera extract-A bioresource for the reduction of ammonia from mariculture. Bioresour. Technol. 2010, 101, 5652-5657. [CrossRef]

28. Barot, N.S.; Bagla, H.K. Eco-friendly waste water treatment by cow dung powder (Adsorption studies of $\mathrm{Cr}(\mathrm{III}), \mathrm{Cr}(\mathrm{VI})$ and Cd(II) using tracer technique). Desalination Water Treat. 2012, 38, 104-113. [CrossRef]

29. Umanu, G.; Nwachukwu, S.C.U.; Olasode, O.K. Effects of Cow Dung on Microbial Degradation of Motor Oil in Lagoon Water. Glob. J. Bio-Sci. Biotechnol. 2013, 2, 542-548.

30. Quraishi, T.; Kenekar, A.; Ranadive, P.; Kamath, G. Evaluation of Performance of cow dung as Microbial Inoculum in Industrial Wastewater Treatment and its Environmental Implications. Indian J. Sci. Technol. 2018, 11, 1-7. [CrossRef]

31. Randhawa, G.K.; Kullar, J.S. Bioremediation of Pharmaceuticals, Pesticides, and Petrochemicals with Gomeya/Cow Dung. ISRN Pharmacol. 2011, 2011, 362459. [CrossRef] [PubMed]

32. Tanvi Godambe, M.H.F. Cow dung Bacteria offer an Effective Bioremediation for Hydrocarbon-Benzene. Int. J. Biotechnol. Trends Technol. 2016, 6, 13-20.

33. Sawant, A.A.; Hegde, N.V.; Straley, B.A.; Donaldson, S.C.; Love, B.C.; Knabel, S.J.; Jayarao, B.M. Antimicrobial-resistant enteric bacteria from dairy cattle. Appl. Environ. Microbiol. 2007, 73, 156-163. [CrossRef] [PubMed]

34. Marler, L.; Allen, S.; Siders, J. Rapid enzymatic characterization of clinically encountered anaerobic bacteria with the API ZYM system. Eur. J. Clin. Microbiol. 1984, 3, 294-300. [CrossRef] [PubMed]

35. Adebusoye, S.A.; Ilori, M.O.; Amund, O.O.; Teniola, O.D.; Olatope, S.O. Microbial degradation of petroleum hydrocarbons in a polluted tropical stream. World J. Microbiol. Biotechnol. 2007, 23, 1149-1159. [CrossRef]

36. Akinde, S.B.; Obire, O. Aerobic heterotrophic bacteria and petroleum-utilizing bacteria from cow dung and poultry manure. World J. Microbiol. Biotechnol. 2008, 24, 1999-2002. [CrossRef]

37. Singh, D.; Fulekar, M. Bioremediation of phenol using microbial consortium in bioreactor. Innov. Rom. Food Biotechnol. 2007, 1, 31-36.

38. APHA; AWWA. Standard Methods for the Examination of Water and Wastewater; American Public Health Association: Washington, DC, USA, 2005.

39. Gulhane, H.; Nakanekar, A.; Mahakal, N.; Bhople, S.; Salunke, A. Gomutra (Cow Urine): A Multidimensional Drug Review Article. Int. J. Res. Ayurveda Pharm. 2017, 8, 1-6. [CrossRef]

40. Dhama, K.; Rathore, R.; Chauhan, R.S.; Tomar, S. Panchgavya (Cowpathy): An Overview. Int. J. Cow Sci. 2005, 1, 1-17.

41. Munshi, S.K.; Roy, J.; Noor, R. Microbiological investigation and determination of the antimicrobial potential of cow dung samples. Stamford J. Microbiol. 2018, 8, 34-37. [CrossRef]

42. Thakare, A.; Ahmad, M.; Pande, K.; Metkari, S.; Engineering, C.; College, D.Y.P. Purification of Water by using Cow Dung Ash. Int. J. Eng. Technol. 2019, 6, 393-397.

43. Ojedokun, A.T.; Bello, O.S. Sequestering heavy metals from wastewater using cow dung. Water Resour. Ind. 2016, 13, 7-13. [CrossRef]

44. Verma, L. Indigenous Technology Knowledge for Watershed Management in Upper North-West Himalayas of India (PWMTA, 1998); FAO (UN): Kathmandu, Nepal, 1998. 